\title{
Physico-chemical, structural and techno-functional properties of gelatin from saithe (Pollachius virens) skin
}

Casanova, Federico; Mohammadifar, Mohammad Amin; Jahromi, Mastaneh; Olander Petersen, Heidi; Eybye, Karin Loft; Kobbelgaard, Sara; Jakobsen, Greta; Jessen, Flemming

Published in:

International Journal of Biological Macromolecules

Link to article, DOI:

10.1016/j.ijbiomac.2020.04.047

Publication date:

2020

Document Version

Peer reviewed version

Link back to DTU Orbit

Citation $(A P A)$ :

Casanova, F., Mohammadifar, M. A., Jahromi, M., Olander Petersen, H., Eybye, K. L., Kobbelgaard, S., Jakobsen, G., \& Jessen, F. (2020). Physico-chemical, structural and techno-functional properties of gelatin from saithe (Pollachius virens) skin. International Journal of Biological Macromolecules, 156, 918-927.

https://doi.org/10.1016/j.ijbiomac.2020.04.047

\section{General rights}

Copyright and moral rights for the publications made accessible in the public portal are retained by the authors and/or other copyright owners and it is a condition of accessing publications that users recognise and abide by the legal requirements associated with these rights.

- Users may download and print one copy of any publication from the public portal for the purpose of private study or research.

- You may not further distribute the material or use it for any profit-making activity or commercial gain

- You may freely distribute the URL identifying the publication in the public portal 


\section{Journal Pre-proof}

Physico-chemical, structural and techno-functional properties of gelatin from saithe (Pollachius virens) skin

Federico Casanova, Mohammad Amin Mohammadifar, Mastaneh Jahromi, Heidi Olander Petersen, Karin Loft Eybye, Sara Kobbelgaard, Greta Jakobsen, Flemming Jessen

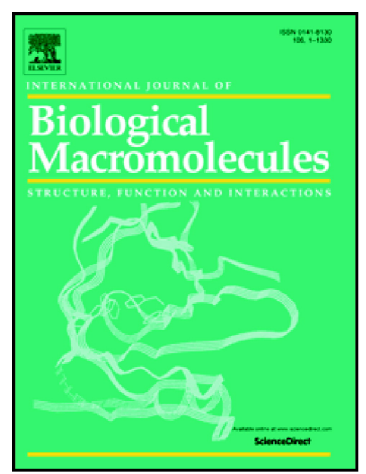

PII: $\quad$ S0141-8130(20)32901-9

DOI: $\quad$ https://doi.org/10.1016/j.ijbiomac.2020.04.047

Reference: $\quad$ BIOMAC 15256

To appear in: $\quad$ International Journal of Biological Macromolecules

Received date: $\quad 11$ November 2019

Revised date: $\quad 31$ March 2020

Accepted date: $\quad 3$ April 2020

Please cite this article as: F. Casanova, M.A. Mohammadifar, M. Jahromi, et al., Physicochemical, structural and techno-functional properties of gelatin from saithe (Pollachius virens) skin, International Journal of Biological Macromolecules (2020), https://doi.org/ 10.1016/j.ijbiomac.2020.04.047

This is a PDF file of an article that has undergone enhancements after acceptance, such as the addition of a cover page and metadata, and formatting for readability, but it is not yet the definitive version of record. This version will undergo additional copyediting, typesetting and review before it is published in its final form, but we are providing this version to give early visibility of the article. Please note that, during the production process, errors may be discovered which could affect the content, and all legal disclaimers that apply to the journal pertain.

(C) 2020 Published by Elsevier. 
Physico-chemical, structural and techno-functional properties of gelatin from saithe (Pollachius virens) skin

Federico Casanova ${ }^{\text {a }}$, Mohammad Amin Mohammadifar ${ }^{a}$, Mastaneh Jahromi ${ }^{\text {a }}$, Heidi Olander Petersen ${ }^{a}$, Karin Loft Eybye ${ }^{b}$, Sara Kobbelgaard ${ }^{b}$, Greta Jakobsen ${ }^{c}$, Flemming Jessen ${ }^{\text {a }}$

${ }^{a}$ Research Group for Food Production Engineering, National Food Institute, Technical University of Denmark, Søltofts Plads, 2800 Kongens Lyngby, Denmark.

${ }^{\text {b }}$ Technological Institute, Kongsvang Alle 29, DK-8000 Aarhus C, Denmark.

${ }^{c}$ Danish Fish Protein, Adelvej 11, Hoejmark, DK-6940 Lem St, Denmark.

* Corresponding author

Tel: (+45) 45252716

E-mail address: feca@food.dtu.dk 


\section{Introduction}

Seafood product plays an important role in human nutrition with a large contribution of proteins, polysaccharides, vitamins, omega-3 and omega- 6 fatty acids [1]. Industrial operations produce more than $60 \%$ of by-products i.e. viscera, head, bones and skin that are often discarded, causing serious environmental problems [2]. An alternative is to convert by-product in fertilizer, pet food or feed. In the last years, with the development of new purification and extraction techniques, seafood by-product is converted into products which are safe and acceptable for the consumer. According to Sila and Bougatef [3], seafood contains several components such as protein, enzymes, glycosaminoglycans, chitin, minerals, carotenoids and collagen. Gelatin is obtained by partial thermal hydrolysis of collagen and it is an important hydrocolloid and a high molecular-weight biodegradable macromolecule [4]. Gelatin exhibits different functional properties, such as water-binding capacity, film-forming properties, foaming and emulsifying abilities, making it a versatile ingredient in the food, pharmaceutical, photography and cosmetic industries [5].

The most abundant sources of gelatin are pig skin, bovine hide and pork and cattle bones that often do not meet the changes in consumption trends, due to ecological problems, animal welfare, allergies, sanitary and religious restrictions. On the other hand, gelatin from aquatic source is not associated to viral infections or the risk of contamination with bovine spongiform encephalopathy [6]. Therefore, fish collagen is a good alternative to mammals collagen as a source of gelatin [7].

With an annual catch of around 300.000 tones, saithe is one of the economically important fish species in North Atlantic sea [8]. It has been widely used for fillet production, generating a large amount of by-products. The aim of this work, was to extract gelatin with high sea mineral content from saithe skin. Two different saithe skin gelatin products were manufactured and investigated in terms of physico-chemical, structural and techno-functional properties in comparison with two commercial gelatin products all from cold water species. Moisture, ash and fat content, amino acid and mineral composition and protein profile by SDS-PAGE were analyzed to obtain their physicochemical composition. Fourier transform infrared (FTIR) spectroscopy was employed to study the changes in functional groups and secondary structures of gelatin, 
whereas differential scanning calorimetry (DSC) was used to explore their thermal properties. Solutions of gelatins were characterize in terms of $\zeta$-potential and functional properties, by measuring foaming properties.

\section{Materials and methods}

2.1. Raw material and preparation of the skin

Sample A, Naticol 4000 - Marine Collagen, from Weishardt International s.r.o., Priemyselná č. 1, (Liptovsky Mikuláš - SK). Sample B, gelatin from cold water fish skin, by Sigma (Sigma, St. Louis, Missouri, US). Sample C and D were obtained from saithe (Pollachius virens) skin provided by a fish processing company in Hanstholm, DK. Regarding the sample $\mathrm{C}$, the skin was pre-treated with neutrase (0.5 AU-N per kg skin) in water (skin : water weight ratio 1:1) for $30 \mathrm{~min}$ at $40{ }^{\circ} \mathrm{C}$, and then rinsed with water. For the extraction the skin was placed in water $(1: 1)$ and the solution was adjusted to $\mathrm{pH} 2$ using $\mathrm{HCl}(15 \%)$ and kept at that $\mathrm{pH}$ for $35-40$ min. Then it was heated to $80{ }^{\circ} \mathrm{C}$ and incubated for $5 \mathrm{~min}$ before centrifugation $\left(5 \mathrm{~min}, 210{ }^{*} \mathrm{~g}\right.$ ). The solution was adjusted at $\mathrm{pH} 6.5$ using $\mathrm{NaOH}(4.5 \mathrm{~N})$ and centrifuged for 5 min at $2100{ }^{*} \mathrm{~g}$ ). The supernatant was then spray dried. Regarding the sample $D$, the skin was pre-treated with neutrase (0.5 AU-N per kg skin) in water (1:1) for 10 min at $40^{\circ} \mathrm{C}$, and then rinsed with water. For the extraction, the skin placed in water (1:1) and the solution was adjusted to $\mathrm{pH} 3.5$ using citric acid and kept at that $\mathrm{pH}$ for $30 \mathrm{~min}$. Then it was heated to $80^{\circ} \mathrm{C}$ and incubated for $5 \mathrm{~min}$ before centrifugation ( $5 \mathrm{~min}, 210{ }^{*} \mathrm{~g}$ ). The solution was adjusted at $\mathrm{pH} 6.5$ using $\mathrm{NaOH}(4.5 \mathrm{~N})$ and centrifuged (5 min at $2100{ }^{*} \mathrm{~g}$ ). The supernatant was then spray dried.

\subsection{Chemical composition}

Moisture and ash content were determined according to the AOAC standard methods 930.15 and 942.05, respectively [9]. Crude fat was determined according to Bligh \& Dyer method [10] with the reduced use of solvent. Total nitrogen content was determined using Dumas method [11]. Conversion factor of 6.25 was used for the conversion of nitrogen to protein content. 


\subsection{Determination of gel strengths (bloom strenght)}

Gel strength of the samples was determined using the method described by Wainewright [12] and Bath et al. [13] with some modifications. Briefly, gel at $6.67 \%$, w/v was prepared in Bloom jars (Schott Duran, Mainz, Germany) (150 ml capacity) by dissolving dry gelatin powder in distilled water at $60^{\circ} \mathrm{C}$ (for $1 \mathrm{~h}$ ) and then cooling the same at room temperature $\left(25 \pm 1{ }^{\circ} \mathrm{C}\right.$ during $\left.15 \mathrm{~min}\right)$. The solution was stored in a refrigerator $\left(4-7^{\circ} \mathrm{C}\right)$ overnight followed by determination of the gel strength by using a Texture Analyzer (TA.XT2i Texture Analyzer; Stable Micro Systems, Godalming, Surrey). The load cell was $5 \mathrm{~kg}$, crosshead speed $1 \mathrm{~mm} / \mathrm{s}$, equipped with a $1.18 \mathrm{~cm}$. in diameter, flat-bottomed plunger. The Bloom jar was placed centrally under the plunger and the penetration test was carried out to determine the maximum force (in g) when the probe proceeded to penetrate into the gel to a depth of $4 \mathrm{~mm}$.

\subsection{Amino acid composition}

The amino acid profile was measured after acid hydrolysis $(6 \mathrm{M} \mathrm{HCl})$ in an oven for $18 \mathrm{~h}$ at $110{ }^{\circ} \mathrm{C}$ using $10 \mathrm{mg}$ sample per $\mathrm{mL} \mathrm{HCl}$. After hydrolysis the samples were cooled to room temperature and used both without dilution and after a 3 fold $(1+2)$ dilution with $6 \mathrm{M} \mathrm{HCl}$ in the remaining procedure in order to quantify both high and low abundant amino acids. Then $100 \mu \mathrm{L}$ was diluted with $1.5 \mathrm{~mL} 1 \mathrm{M} \mathrm{NaCO}_{3}$ and filtered through a $0.2 \mu \mathrm{m}$ syringe filter (Q-max PTFE, $\varnothing 13 \mathrm{~mm}$, Frisenette ApS, Knebel, Denmark) before derivatization using the EZ:FaastTM Amino Acid Analysis kit from Phenomenex® (Torrance, CA, USA). The samples $(50 \mu \mathrm{l})$ were then analysed by LC(APCI)-MS (Agilent 1100, Agilent Technology) according to the procedure described by Farvin, Baron, Nielsen, Otte \& Jacobsen [14].

\subsection{Micro and macro elements analysis}

The content of the elements were determined by inductively coupled plasma mass spectrometry (Thermo iCAPq ICPMS, Thermo Electron) following microwave-assisted digestion (Multiwave 3000, Anton Paar, Graz, Austria) using concentrated nitric acid (SPS Science, Paris, France). The sample digests were diluted with ultrapure water (milli-Q) prior to analysis. Quantification was done by external calibration with internal standardization using yttrium as internal standard. All standards were prepared from 
certified stock solutions (SPS Science). A certified reference material (DORM-4 fish protein, NRCC, Canada) was used for quality assurance of the analytical results.

\subsection{Electrophoretic study (SDS-PAGE)}

Protein profile of samples were determined by polyacrylamide gel electrophoresis performed in Mighty Small (Hoefer) slab cell according to the method of Laemmli [15] using $12 \%$ acrylamide $(\mathrm{C}=2.6 \%(\mathrm{w} / \mathrm{w}))$ slab gels $(1.5 \mathrm{~mm}$ thick). The dry sample (50 $\mathrm{mg}$ ) was extracted in $2 \mathrm{~mL} 1 \%$ sodium dodecyl sulfate (SDS), $100 \mathrm{mM}$ dithiothretiol (DTT) and $60 \mathrm{mM}$ Tris $\mathrm{HCl}(\mathrm{pH}$ 8.3). After gentle shaking at room temperature for $1 \mathrm{~h}$ the sample was mixed/homogenized (Polytron PT 1200, Kinematica) for $30 \mathrm{~s}$, boiled for $2 \mathrm{~min}$ and incubated at room temperature $\left(\mathrm{R}^{\circ} \mathrm{C}\right)$ for $30 \mathrm{~min}$. The sample was then homogenized, and boiled again for $2 \mathrm{~min}$ and centrifuged for $15 \mathrm{~min}$ at $20{ }^{\circ} \mathrm{C}$ at $20.000 \mathrm{~g}$. The supernatant was collected. An extract aliquot was diluted with sample buffer (125 mM Tris $\mathrm{HCl}$ ( $\mathrm{pH}$ 6.8), 2.4\% SDS, $50 \mathrm{mM}$ DTT, 10\% v/v glycerol, $0.5 \mathrm{mM}$ EDTA and bromphenol blue) in order to load the gel with $10 \mu \mathrm{L}$, corresponding to $40 \mu \mathrm{g}$ protein based on the protein content of the dry sample. The electrophoresis was run at constant voltage: $100 \mathrm{~V}$ for $15 \mathrm{~min}$ followed by $150 \mathrm{~V}$ for $1 \mathrm{~h}$ (max. $40 \mathrm{~mA}$ per gel) and afterwards the gel was stained using colloidal Coomassie Brilliant Blue as described by Rabilloud and Charmont [16]. Mark12 ${ }^{\mathrm{TM}}$ from Novex was used as molecular weight markers.

\subsection{Fourier transform infrared (FTIR) spectroscopy}

FTIR spectrum of equilibrated gelatin samples $(11 \% \mathrm{RH})$ was recorded in a PerkinElmer Spectrum 100 FT-IR spectrometer (Waltham, Massachusetts, USA) between 650 and $4000 \mathrm{~cm}^{-1}$ at a resolution of $4 \mathrm{~cm}^{-1}$. Automatic signal were recorded in 4 scans. Each measurement was repeated 3 times.

\subsection{Differential scanning calorimetry (DSC)}

Unfolding, glass transition, solid melting temperatures of gelatin samples at $11 \%$ relative humidity were measured by differential scanning calorimetry DSC 250 (TA 
Instruments, New Castle, Delaware, USA), equipped with Refrigerated Cooling System 90. The instrument was calibrated for heat flow and temperature using distilled water (melting point (m.p.) $=0 \mathrm{C} ; \mathrm{DHm}=334 \mathrm{~J} / \mathrm{g}$ ) and indium (m.p. $=156.5 \mathrm{C} ; \mathrm{DHm}=28.5$ $\mathrm{J} / \mathrm{g}$ ). Aluminum pans of $30 \mathrm{IL}$, which could be sealed with hermetic lid, were used in all experiments with an empty sealed pan as reference. Nitrogen at a flow rate of 50 $\mathrm{mL} / \mathrm{min}$ was used as a carrier gas. Approximately $5 \mathrm{mg}$ of a gelatin sample was placed in an aluminum pan, sealed and cooled to $-90^{\circ} \mathrm{C}$ and kept for $5 \mathrm{~min}$. After equilibration, the sample was scanned from $-90^{\circ} \mathrm{C}$ to $200^{\circ} \mathrm{C}$ at a heating rate of $5{ }^{\circ} \mathrm{C} / \mathrm{min}$. According to Al-Saidi et al. [17], the glass transition, thermal unfolding and solidsmelting characteristics were determined from the curve. Glass transition was analyzed for the onset, mid, and end points from the shift in the curve line. Thermal unfolding and melting peaks were characterized from initial, maximum slope and peak whereas enthalpy from the area of the endothermic peak. All the thermograms were analyzed using Trios software. Each measurement was repeated 3 times.

\section{9. $\zeta$-potentials}

$\zeta$-potential of samples were analyzed according to the protocol described by Chen et al. [18] with slight modifications. Briefly, gelatin samples were dissolved in Milli-Q water to obtain a final concentration of $0.5 \mathrm{~g} / \mathrm{L}$. The mixtures were continuously stirred at 25 ${ }^{\circ} \mathrm{C}$ during $12 \mathrm{~h}$ until completely dissolution. The $\zeta$-potential of gelatin solutions was measured with Zetasizer Nano-ZS (Malvern Instruments, Worcestershire, UK) using capillary cells. Using a titration instrument (MPT-2, Malvern Instruments, Worcestershire, UK) the $\mathrm{pH}$ of the sample $(10 \mathrm{~mL})$ was adjusted within a $\mathrm{pH}$ range from 2 to 9 with $1 \mathrm{M} \mathrm{KOH}$ and $1 \mathrm{M} \mathrm{HNO}_{3}$. $\zeta$-potential was calculated from the electrophoretic mobility $(\mu)$ using the Henry equation, as shown below:

$$
\zeta=\frac{3 n \mu}{2 \epsilon f(k R h)}
$$

Where $n$ is the viscosity of buffer $\left(1.033 \times 10^{-3} \mathrm{~Pa} \mathrm{~s}^{-1}\right), \epsilon$ is the medium dielectric constant (dimensionless), $R h$ is the complex radius $(n m)$ and $f(k R H)$ is the Henry's function. Because the analysis is conducted in aqueous media, a value of 
1.5 was adopted $\mathrm{f}(k R h)$, which is referred to as the Smoluchowski approximation. The isoelectric point $(\mathrm{pl})$ was determined from a $\mathrm{pH}$ rendering a zero potential.

\subsection{Interfacial rheology with double wall ring (DWR)}

Interfacial rheology was measured using a sensitive stress-controlled rheometer (DHR2, TA Instruments, New Castle, USA) equipped with a double wall-ring (DWR) geometry. According to Vandebril et al. [19] the sample was contained in a thin, squareedged ring and used with a Delrin ${ }^{\circledR}$ trough with a circular channel and a ring was positioned at the air/liquid interface. Amplitude sweep measurement was performed in the strain \% ranging from 0.01 to $100 \%$ at frequency of $1 \mathrm{~Hz}$ in order to obtain the linear viscoelasticity range. Frequency sweep analysis was performed over a range of 0.1 to $20 \mathrm{~Hz}$ at linear viscoelastic region (strain \% =0.2). Time sweep, at linear viscoelastic region, was investigated during $800 \mathrm{~min}$ at frequency of $1 \mathrm{~Hz}$.

All experiments were performed at thermostated constant temperature $\left(20 \pm 0.01^{\circ} \mathrm{C}\right)$ by placing $20 \mathrm{~mL}$ of sample directly into trough.

\subsection{Foaming properties}

Foaming properties of samples were measured according to Jarpa-Parra et al. [20] with slight modifications. Briefly, a gelatin powder was rehydrated in distilled water $(\mathrm{C}=20 \mathrm{~g} / \mathrm{l})$ and left $12 \mathrm{~h}$ at $25^{\circ} \mathrm{C}$ for swelling. The foam was prepared by homogenizing $50 \mathrm{~mL}$ of solution with an Ultraturrax mixer (Colonial Scientific, DI 25 basic yellow line, Richmond, USA) at 9,500 rpm for $1 \mathrm{~min}$. The homogenized solution was spilled into a $100 \mathrm{~mL}$ graduated cylinder sealed with parafilm. The foaming capacity $(F C)$ was calculated according to Eq. (2), where $V_{t}$ and $V_{0}$ represent the formed foams after homogenization, and the volume of the protein solution, respectively. The foaming stability $(F S)$ was calculated according to Eq. (3), where $V_{\text {t time }}$ represents the volume of foam that remained after standing for $5,10,15,30,60 \mathrm{~min}$ at $20^{\circ} \mathrm{C}$.

$$
F C=\frac{V_{t-} V_{0}}{V_{0}} \times 100 \%
$$




$$
F S=\frac{V_{\text {time }}}{V_{0}} \times 100 \%
$$

All the experiments were conducted in duplicate by the same person at room temperature.

\subsection{Color determination}

The color of the powder surface where measured with a colorimeter Minolta Chroma Meter CR-400. The samples are measured in the $L{ }^{*} a{ }^{*} b$ * system. The $L$ value (black/white scale) is \pm 100 , the a value (red/green scale) and the b value (yellow/blue scale) from -128 to +127 . All samples were measured 10 times on the powder surface with powder measuring head.

\section{Results and discussion}

\subsection{Physico-chemical composition}

The chemical composition, including moisture, ash, protein and fat of different samples are given in Table 1. Sample A, $C$ and $D$ had moisture contents between 4.81 $\%$ and $7.09 \%$ whereas sample $B$, present a higher value of $11.73 \%$. The maximum ash content recommended for gelatin is $2.6 \%$ [21]. The reported ash values (Table 1) indicated a significant difference between samples and revealed the presence of two distinct groups: sample $A$ and $B$ that present ash values lower than $0.2 \%$, whereas $C$ and $D$ have very high values around $25 \%$. The protein content divided the samples in two significantly different groups: A and B with high protein content (around $95 \%$ ) and $\mathrm{C}$ and $\mathrm{D}$ with lower content $(<75 \%)$. This difference between the samples is probably caused by the different treatments utilized for extraction and purification [22]. The fat content for all the samples is lower than $1 \%$, suggesting efficient removal of fat from the skin material.

Out of $\sim 17 \mathrm{Kg}$ and $\sim 12 \mathrm{Kg}$ of the descaled skin for sample $\mathrm{C}$ and $\mathrm{D}, \sim 1 \mathrm{Kg}$ of extracted gelatin was obtained respectively. This can be translated to the yield of $5.8 \%$ and $8.3 \%$ for sample $C$ and $D$ (based on wet weight matter). From the literature, different yield of extractions are reported: black tilapia (5.4\%), red tilapia (7.8\%) [23], 
young Nile perch (12.3\%), adult Nile perch (16.0\%) [24], sin croaker (14.3\%), shortfin scad (7.3\%) [25], bigeye snapper (6.5\%), Nile tilapia (18.1\%) [26]. The observed variation in the extraction yield depends on the differences in the proximate composition of the skins, the collagen content, the amount of soluble components in the skins, the species and the age of the fish, as well as the variation in the extraction method [26].

Bloom gel strenght is an important physical property of the gelatin [26]. The bloom gel strenght of the extracted gelatin was 1.9 and $7.7(\mathrm{~g})$, for the sample $C$ and $D$, and 3.3 and $8.1(\mathrm{~g})$ for the sample $A$ and $B$, respectively (Figure of the gels is provided as Supplementary File 1). In the litterature, different values were reported for gelatin extracted from skin of other fish species: black tilapia (181 g), red tilapia (128 g) [23], cod (70 g), hake (100 g), megrim (340 g), sole (350 g) [27] and young Nile perch (81$222 \mathrm{~g}$ ), adult Nile perch (134-229 g) [24]. We observed lower gelatin strenght values for sample $C$ and $D$, compared to other fish species. However, this variation depends on many factors, like different compositions of amino acids, size of protein chains, concentration and molecular weight distribution of the obtained gelatin [26].

\subsection{Color determination}

The lightness $\left(L^{*}\right)$, redness $\left(a^{*}\right)$ and the yellowness $\left(b^{*}\right)$ of the commercial product $(A$ and $B$ ), compared to gelatin from saithe skin (C and $D)$ are reported in Table 1. Sample $A$ and $B$, in their powder state, appeared in yellow-brown color, with a lightness of 94.2 and 79.8, respectively. The powder of extracted gelatin (sample $C$ and D) present brightness color, showing $L^{*}$ values higher than 96.7. Commercial gelatin appeared to be yellow compared to gelatin extracted from saithe, which $b^{*}$ values of 13.2 and 27.2 for $A$ and $B$ and 4.58 and 4.25 for $C$ and $D$. Furthermore, gelatin from saithe had a low $b^{*}$ value compared to gelatin extracted from Nile Tilapia (O. niloticus) [26] and sin croaker (Johnius dussumieri) [25], which present respective values of 23.8 and 13.65. According to Songchotikunpan et al. [26], the color of gelatins depends on the raw materials and, in general, the color does not influence their functional properties. We can conclude that the visual observations of gelatin from saithe present a positive 
attribute, since it will be easier to incorporate them into any food system without imparting any strong colour attribute to the product.

\subsection{Amino acid composition}

Amino acid composition of sample A, B, C and D, expressed as number of residues/1000 residues, is presented in Table 2. According to Sila et al. [28], the properties of gelatin is influenced by the amino acid composition. Our results showed that the most abundant amino acid present was glycine, followed by proline and alanine. In addition a high content of glutamic acid was observed. All the samples present low contents of methionine, isoleucine and tyrosine. No contents of tryptophan was observed. In general, gelatin contains approximately $33 \%$ glycine, $12 \%$ proline and $11 \%$ alanine [29]. According to Amiza and Aishah [30], the imino acids proline and hydroxyproline, give rigidity to the gelatin structure; on the other hands, limited imino acid content results in a less sterically hindered helix and affect the dynamic properties of gelatin. In our case, the imino acid content of sample A, B, C and D was respectively 206, 162, 178 and 163 residues/1000 residues, respectively. Similar results on imino acid contents were found by Kittiphattanabawon et al. [31] on grass carp skin collagen (186 residues/1000 residues) and bigeye snapper skin collagen (193 residues/1000 residues). However, Singh et al. [32] found a slightly higher imino acid content in striped catfish skin collagen (206 and 217 residues/1000 residues from extraction of acid soluble collagen and pepsin soluble collagen, respectively). Generally, the variation in imino acid contents between different species is mainly due to the different living environments, habitat, temperature and season [32].

\subsection{Micro and macro elements}

As presented in Table 3, analysis of mineral composition showed two different group: commercial sample ( $A$ and $B$ ) and gelatin from saithe skin ( $C$ and $D)$. The major mineral present was $\mathrm{Na}$, with high levels for sample $\mathrm{C}$ and $\mathrm{D}$ compared to $\mathrm{A}$ and $\mathrm{B}$. According to Jongjareonrak, Benjakul, Visessanguan, and Tanaka [33], fish gelatins contain low levels of magnesium. In our study, sample $C$ and $D$ present higher values than those contained in the pork gelatin $(0.214 \mathrm{~g} / \mathrm{Kg}$ dry matter [34]). Higher content of calcium was observed for sample $C$ and $D$ compared to commercial gelatin $A$ and $B$. The order of 
the elements levels in gelatin D was determined as following: $\mathrm{Sr}>\mathrm{Fe}>\mathrm{Zn}>\mathrm{Cr}>\mathrm{Ni}>$ $\mathrm{Mn}>\mathrm{Cu}>\mathrm{Se}>\mathrm{Co}$. Sample C contained more Se and less of all the others elements compared to sample D. On the other side, and except for Fe, Co and Se, gelatin A and $B$ had lower amount of microelements compared to samples $C$ and $D$. Lower value of cadmium was observed in sample $D(<0.01)$. Mercury content in all the studied samples were lower than $0.01 \mathrm{~g} / \mathrm{kg}$ dry matter. Castro-González, M. Méndez-Armenta [35], reported that carp muscle contains $0.016 \mathrm{mg}$ of $\mathrm{Cd} / \mathrm{kg}, 0.11-0.28 \mathrm{mg}$ of $\mathrm{Hg} / \mathrm{kg}$, $0.21-0.43 \mathrm{mg}$ of $\mathrm{Pb} / \mathrm{kg}$ and $0.16-0.17 \mathrm{mg}$ of $\mathrm{As} / \mathrm{kg}$. These results are much higher than the reported values in this study. It seems that lower amount of heavy metal in gelatin samples from Saithe skin could be related to the lower tendency of this species in accumulating these contaminates.

\subsection{Protein profile (SDS-PAGE)}

Polyacrylamide gel electrophoresis in the presence of SDS was employed to analyze the protein profile of the gelatin samples. Approximate molecular weight distribution of sample $A, B, C$ and $D$ is compared and presented in Fig. 1. In the case of sample $A$ and $B$, the distinct bands corresponding to the main components of collagen (the $\gamma$ and $\beta$ chains) were not observed. In sample A only two weak bands, between 66 and $55 \mathrm{kDa}$ and some bands below the $31 \mathrm{kDa}$ marker protein, were observed. This result indicated that an extensive hydrolysis of collagen has occurred during the production process of sample A. In sample B protein staining with indistinct bands were found at all molecular weights above $21 \mathrm{kDa}$ with the most intense staining in the range from 55 to $>200 \mathrm{kDa}$. Why Sample $\mathrm{B}$ has this protein profile is unknown, but it could eventually be due to a very mild unspecific hydrolysis of collagen or aggregation. Sample C and D showed typically electrophoresis patterns of type I collagen, with the presence of $\gamma$-chains, $\beta$-chains and other high molecular weight aggregates. In addition, high levels of $\alpha$-chains polymers (dimmers and trimmers) allow to obtain higher gel strenght [36]. Additional bands, at lower molecular weight $(<100 \mathrm{kDa})$ were observed. According to Kołodziejska et al. [37], this is probably due to hydrolysis of the 
basic collagen chains or the residues of non-collagenous proteins. The reason for these differences might be the extraction conditions including use of different enzymes.

\subsection{FTIR spectra}

FTIR spectra of the samples are shown in Fig. 2. FTIR is a non-destructive, rapid and easily technique employed to obtain a biochemical fingerprint of proteins. According to [38] and [39], FTIR can provide information about the molecular structure and composition in functional groups and secondary structures of proteins. It has been reported that generally, all types of gelatin present a more or less similar spectra [40]. Fig. 2 indicates five distinct regions for FTIR spectra of the gelatin samples: 3600-2300 (amide A), 3069-2940 (amide B), 1641-1633 (amide I), 1536-1516 (amide II) and 1270$1233 \mathrm{~cm}^{-1}$ (amide III). According to Doyle, Bendit and Blout [41], a free N-H stretching vibration occurs in the range of $3400-3440 \mathrm{~cm}^{-1}$. When the $\mathrm{NH}$ group of a peptide is involved in a hydrogen bond, the position is shifted around $3300 \mathrm{~cm}^{-1}$. According to our spectra, it seems that the $\mathrm{NH}$ groups of this gelatin were involved in hydrogen bonding, probably with a carbonyl group of the peptide chain. Amide B band has split into two peaks for all the samples. These two values of wavenumbers, represent the asymmetric and symmetric stretching of $\mathrm{C}-\mathrm{H}$. The Amide I, II and III bands are responsible for the degree of molecular order found in collagen and involved in the formation of triple helical structure due to $\mathrm{C}=\mathrm{O}$ stretching, $\mathrm{N}-\mathrm{H}$ bending and $\mathrm{C}-\mathrm{H}$ stretching [42]. The Amide I has characteristics frequencies from 1600 to $1700 \mathrm{~cm}^{-1}$, which is mainly associated to the stretching vibrations of the carbonyl group $\mathrm{C}=\mathrm{O}$. The frequency range of 1640 to $1620 \mathrm{~cm}^{-1}$ represent the $\beta$-sheet structure [43]. The wavenumber in the range of $1550-1540 \mathrm{~cm}^{-1}$ and $1525-1520 \mathrm{~cm}^{-1}$ correspond to the $\alpha$-helical and $\beta$-sheet structure respectively, caused by amide II region. According to FTIR results (Fig. 2), the samples $A, B, C$ and $D$ presented peak wave number at 1520, 1536, 1527 and 1533 $\mathrm{cm}^{-1}$, respectively. According to [33], this band is typically sensitive to hydration than to structural changes in protein. Amide III band was detected at 1233, 1247, 1247 and $1270 \mathrm{~cm}^{-1}$, for the samples A, B, C and D respectively. According to Nagajaran et al. [44], the amide III represents the combination peaks between C-N stretching vibrations 
and $\mathrm{N}-\mathrm{H}$ deformation from amide linkages as well as absorptions arising from wagging vibrations from $\mathrm{CH}_{2}$ groups from the glycine backbone and proline side-chains. Results showed that sample A, B and C have lower amplitudes compared to sample D. The transformation of an $\alpha$-helical to a random coli structure is associated with a pretreatment employed, causing a higher disorder of the molecular structure. According to Muyonga [42] et al., this loss of structure is a results of denaturation of collagen to gelatin.

\subsection{Thermal stability}

DSC analysis provides sensitive means of understanding the heat induced denaturation of gelatin samples [45]. DSC thermograms of sample A, B, C and D, equilibrated at $11 \% \mathrm{RH}$, are shown in Fig. 3. All the thermograms are marked with $\mathrm{a}, \mathrm{b}$ and $\mathrm{c}$ for the glass transition $(\mathrm{Tg})$, unfolding and solids-melting temperature, respectively. $\mathrm{Tg}$ was observed between 69.3 and $77.1^{\circ} \mathrm{C}$ for the all samples. Rahman et al. [17] observed $\mathrm{Tg}$ of extracted gelatin from tuna skin at $-24^{\circ} \mathrm{C}$, Al-Saidi et al. [46], for shaari fish skin found $\mathrm{Tg}$ at $-15^{\circ} \mathrm{C}$, whereas Rahman et al. [17] on porcine and bovine gelatin, reported $\mathrm{Tg}$ values of 29 and $30^{\circ} \mathrm{C}$ respectively. The wide variation of the $\mathrm{Tg}$ values in the literature may be due to different types of gelatin transformed during different extraction method and characteristics of animal skins based on species, age, and sex [46]. Unfolding temperature was presented in Table 6. Sample A, B and C presented a temperature of $146^{\circ} \mathrm{C}$, while sample $\mathrm{D}$ present an unfolding temperature of $156^{\circ} \mathrm{C}$. The shift of $\sim 10^{\circ} \mathrm{C}$ toward high temperature of sample $\mathrm{D}$ is probably due to the protocol extraction in citric acid compared to HCl. According to Giménez et al. [47], gelatin is a very complex molecule and its thermal characteristics depend on many factors, such as the collagen type, tissue, animal species, and age. The value of melting temperature was founded at $168.1,189.8,165.7$ and $175.1{ }^{\circ} \mathrm{C}$ for the sample $\mathrm{A}, \mathrm{B}, \mathrm{C}$ and $D$, respectively. This results clearly indicated that the breakage of peptide chains and subsequent destruction of materials is taking place at various temperatures for gelatin samples [48]. No generic trend was observed as a function of extraction. Similar values were found by Al-Saidi et al. [46] for gelatin extracted from shaari skin. The enthalpy of melting $(\Delta \mathrm{H}(\mathrm{J} / \mathrm{g}))$, determined from the area under the endothermic peak, 
show 2.68, 9.11 and $7.88(\mathrm{~J} / \mathrm{g})$ for sample $A, C$ and $D$ whereas a value of $97.64(\mathrm{~J} / \mathrm{g})$ for sample B. Reduction of those peaks is an indication that the proteins under consideration partially lost their native form. The higher $\Delta \mathrm{H}$ for sample $\mathrm{B}$ might be associated with the difference in amino acid contents.

\section{8. $\quad \zeta$ - potential}

$\zeta$-potential is the $e^{-}$potential difference between dispersion medium and the surface of the dispersed protein. A numerical high $\zeta$-potential indicates stability to avoid aggregation and a numerical small $\zeta$-potential value close to zero, ascribes to increased hydrophobic-hydrophobic interactions, resulting in protein precipitation and aggregation [32]. The $\zeta$-potential data showed that all the samples were positively charged in the $\mathrm{pH}$ range 2-6 and negatively charged between $\mathrm{pH} 7-11$. By intersection of curve on X-axe at $0 \mathrm{mV}$, a pl value was measured at $6.6,6.97,6.33$ and 5.63 for the sample $A, B, C$ and $D$, respectively. Gelatin extracted with acid and pepsin from fish scraps had $\mathrm{pl}$ values from 6.21 to 6.56 [49].

\subsection{Interfacial rheology}

Interfacial rheological measurements at air-liquid interface is a suitable method to reflect the kinetic of macromolecules absorption at interface and strength of the adsorbed layer, and to predict the foam stability of macromolecules [50]. The Fig. 5 $A$ and $B$ presents the air-liquid interfacial viscoelastic behavior of the gelatin solutions, at linear viscoelastic region (strain $\%=0.2$ ), as a function of frequency (0.1 to $20 \mathrm{~Hz})$ and time (800 $\mathrm{min})$, respectively. According to the frequency sweep measurements (Fig. 5 A), higher elastic moduli ( $G$ ') was observed for the sample $C$, compared to samples $B, D$ and $A$. Samples $B$ and $C$ showed predominantly elastic behavior (G'> G") within the whole test frequency. However, the difference between the values of $G$ ' and $G$ " is more pronounced in sample $C$. Samples $A$ and $D$ revealed a predominant elastic behavior at low frequencies (G'> G") and viscous behavior at high frequencies ( $\left.G^{\prime}<G^{\prime \prime}\right)$. This behavior may be attributed to an association between protein aggregates as they are confined at the surface, leading to formation 
of an elastic film at air-liquid interface [51]. Time sweep measurements (Fig. 5 B) exhibited different kinetics of interfacial viscoelasticity development in the samples over time. Sample B showed a viscous dominant behavior ( $\left.G^{\prime}<G^{\prime \prime}\right)$ during the measured time with a steady value of viscous moduli (G") and slight increase in elastic moduli until reaching a plateau. However, samples $C$ and $D$ showed a dominant elastic behavior during the whole test with a rapid initial raise in G', significantly in sample $\mathrm{C}$, and further slower increase until reaching a plateau. Rapid increase in $\mathrm{G}^{\prime}$ component may be correlated with the fast migration and adsorption of protein molecules from the bulk subphase to the air-liquid interface and formation of an elastic interface. According to Jin et al. [50], the stability of foams are strongly affected by the stability and mechanical strength of the interfacial layer. High interfacial elasticity represents more tendency to improve the foam stability.

\subsection{Foaming properties}

Foam capacity (FC) and foam stability (FS) as a function of time, are two of the most important properties of proteins for common food products. Results of FC are presented in Fig. 6 A. FC was observed at $80,94,76 \%$ for the sample A, B and C and the highest at $114 \%$ for the sample D. FS was monitored during $60 \mathrm{~min}$, as reported in Fig. 6 B. Results showed similar trend during the first 10 min: FS was comprised between 81 and $45 \%$, for all the sample. After $15 \mathrm{~min}$, FS of sample A and B drastically decreased to 16 and $26 \%$ respectively, and reached $0 \%$ after $30 \mathrm{~min}$. Sample C and D remained stable at 56 and $52 \%$, respectively, after $15 \mathrm{~min}$. A slight decrease ( $6 \%$ ) was observed after 30 min with a final FS after 60 min of 20 and $23 \%$ respectively. Although the FC for sample A and B was 80 and $94 \%$ respectively, they showed lower FS compared to the sample $C$ and $D$. Smaller molecular weight peptides $(<30 \mathrm{kDa})$ are able to reach the air-liquid interface, resulting in better FC [52]. Afterwards, hydrophobic residues form large hydrophobic sphere at the interface, giving higher FS [53]. In our case, a positive correlation exist between the hydrophobic residues and foam stability. Sample C and D showed peptides size from $200 \mathrm{kDa}$ to $55 \mathrm{kDa}$ whereas sample $\mathrm{A}$ present the lowest content of hydrophobic residues, resulting in lower foam stability. In addition, the long term foam stability, is correlated with the interfacial rheology. Sample 
$C$ and $D$ present higher viscoelastic behavior compared to sample $A$ and $B$, showing strong association of protein at the air-water interface. Finally, it would be concluded that probably, the process conditions affected considerably the foaming properties.

\section{Conclusion}

In this study, a comparison between marine gelatin from the market and gelatin extracted from skin of saithe with high mineral content was presented. No differences in physico-chemical composition were observed, except for ash content, where gelatin extracted from the saithe skin had a high ash content (24\% and $27 \%$ in sample $C$ and $D$, respectively) and gelatin from the market samples had a low ash content $(0.14 \%$ and $0.18 \%$ in sample $A$ and $B$, respectively). SDS-PAGE for gelatin extracted from the saithe skin showed typically electrophoresis patterns of gelatin from type I, with the presence of $\alpha$-chains, $\beta$-chains and other high molecular weight aggregates. The absorption bands of gelatin in FTIR spectra were mainly situated in the amide band region (amide A, Amide B, amide I, amide II and amide III), whereas DSC thermograms showed typical gelatin behavior. Interesting viscoelastic and higher foaming properties were observed for the saithe gelatins, compared to the market gelatins, probably due to the presence of high sea mineral content. This results open new perspectives for possible applications of gelatin $C$ and $D$ as a new microencapsulating agent in a cosmetic area as well as in food applications.

\section{Acknowledgements}

The authors acknowledge the support provided by the Green Development and Demonstration Program (GUDP) and Ministry of Environment and Food of Denmark (J.Nr. 34009-17-1299).

\section{Declaration of competing interest}

The authors declare that there are no conflicts of interest. 


\section{References}

[1] J.G. Gormaz, J.P. Fry, M. Erazo, D.C. Love, Public Health Perspectives on Aquaculture, Curr Environ Heal Reports. 1 (2014) 227-238. doi:10.1007/s40572014-0018-8.

[2] K. Elavarasan, A. Kumar, D. Uchoi, C.S. Tejpal, G. Ninan, A.A. Zynudheen, Extraction and Characterization of Gelatin from the Head Waste of Tiger Tooth Croaker (Otolithes ruber), Waste and Biomass Valorization. 8 (2017) 851-858. doi:10.1007/s12649-016-9639-5.

[3] A. Sila, A. Bougatef, Antioxidant peptides from marine by-products: Isolation, identification and application in food systems. A review, J Funct Foods. 21 (2016) 10-26. doi:10.1016/j.jff.2015.11.007.

[4] A.O. Elzoghby, Gelatin-based nanoparticles as drug and gene delivery systems: Reviewing three decades of research, J Control Release. 172 (2013) 1075-1091. doi:10.1016/j.jconrel.2013.09.019.

[5] T. Ahmad, A. Ismail, S.A. Ahmad, K.A. Khalil, Y. Kumar, K.D. Adeyemi, A.Q. Sazili, Recent advances on the role of process variables affecting gelatin yield and characteristics with special reference to enzymatic extraction: A review, Food Hydrocoll. 63 (2017) 85-96. doi:10.1016/j.foodhyd.2016.08.007.

[6] A.A. Karim, R. Bhat, Fish gelatin: properties, challenges, and prospects as an alternative to mammalian gelatins, Food Hydrocoll. 23 (2009) 563-576. doi:10.1016/j.foodhyd.2008.07.002.

[7] L. Niu, X. Zhou, C. Yuan, Y. Bai, K. Lai, F. Yang, Y. Huang, Characterization of tilapia (Oreochromis niloticus) skin gelatin extracted with alkaline and different acid pretreatments, Food Hydrocoll. 33 (2013) 336-341. doi:10.1016/j.foodhyd.2013.04.014.

[8] D.M. Cohen, T. Inada, T. Iwamoto, N. Scialabba, Fao Species Catalogue an Annotated and Illustrated Catalogue, 1990.

[9] AOAC, Official Methods of Analysis of AOAC INTERNATIONAL, Off Methods Ananlysis AOAC Int. 18th editi (2005) 20877-2417.

[10] E. G. Bligh, W. J. Dyer, A rapid method of total lipid extraction and purification, Can J Biochem Physiol. 37 (8) (1959) 911-957. 
[11] J.B.A., Dumas, Procedes de l'analyse organique, Ann Chim Phys. T47 (1831) 198-213.

[12] F.W. Wainewright, Physical test for gelatin and gelatin products., in: A.P. Inc. (Ed.), Sci Technol Gelatin, In A. G. W, London, 1977: pp. 507-531.

[13] R. Bhat, A.A. Karim, Ultraviolet irradiation improves gel strength of fish gelatin, Food Chem. 113 (2009) 1160-1164. doi:10.1016/j.foodchem.2008.08.039.

[14] N. Maulida Safitri, E. Yuli Herawati, J. Liang Hsu, Antioxidant Activity of Purified Active Peptide Derived from Spirulina platensis Enzymatic Hydrolysates, Res J Life Sci. 4 (2017) 119-128. doi:10.21776/ub.rjls.2017.004.02.5.

[15] U.K. Laemmli, Cleavage of Structural Proteins During Assembly of Head of Bacteriophage-T4., Nature. 227 (1970) 680-685.

[16] S. Rabilloud, T.; Charmont, Detection of proteins on two-dimensional electrophoresis gels, in: Proteome Res Two-Dimensional Gel Electrophor Identif Methods, Springer V, 2000: pp. 107-126.

[17] M.S. Rahman, G.S. Al-Saidi, N. Guizani, Thermal characterisation of gelatin extracted from yellowfin tuna skin and commercial mammalian gelatin, Food Chem. 108 (2008) 472-481. doi:10.1016/j.foodchem.2007.10.079.

[18] J. Chen, L. Li, R. Yi, N. Xu, R. Gao, B. Hong, Extraction and characterization of acid-soluble collagen from scales and skin of tilapia (Oreochromis niloticus), LWT - Food Sci Technol. 66 (2016) 453-459. doi:10.1016/j.Iwt.2015.10.070.

[19] S. Vandebril, A. Franck, G.G. Fuller, P. Moldenaers, J. Vermant, A double wallring geometry for interfacial shear rheometry, Rheol Acta. 49 (2010) 131-144. doi:10.1007/s00397-009-0407-3.

[20] M. Jarpa-Parra, F. Bamdad, Y. Wang, Z. Tian, F. Temelli, J. Han, L. Chen, Optimization of lentil protein extraction and the influence of process $\mathrm{pH}$ on protein structure and functionality, LWT - Food Sci Technol. 57 (2014) 461-469. doi:10.1016/j.Iwt.2014.02.035.

[21] A. da T. Alfaro, E. Balbinot, C.I. Weber, I.B. Tonial, A. Machado-Lunkes, Fish Gelatin: Characteristics, Functional Properties, Applications and Future Potentials, Food Eng Rev. 7 (2014) 33-44. doi:10.1007/s12393-014-9096-5.

[22] A. Abedinia, F. Ariffin, N. Huda, A.M. Nafchi, Extraction and characterization of gelatin from the feet of Pekin duck (Anas platyrhynchos domestica) as affected by acid, alkaline, and enzyme pretreatment, Int J Biol Macromol. 98 (2017) 586-594. doi:10.1016/j.ijbiomac.2017.01.139.

[23] B. Jamilah, K.G. Harvinder, Properties of gelatins from skins of fish - Black tilapia (Oreochromis mossambicus) and red tilapia (Oreochromis nilotica), Food Chem. 77 (2002) 81-84. doi:10.1016/S0308-8146(01)00328-4.

[24] J.H. Muyonga, C.G.B. Cole, K.G. Duodu, Extraction and physico-chemical characterisation of Nile perch (Lates niloticus) skin and bone gelatin, Food 
Hydrocoll. 18 (2004) 581-592. doi:10.1016/j.foodhyd.2003.08.009.

[25] C.S. Cheow, M.S. Norizah, Z.Y. Kyaw, N.K. Howell, Preparation and characterisation of gelatins from the skins of sin croaker (Johnius dussumieri) and shortfin scad (Decapterus macrosoma), Food Chem. 101 (2007) 386-391. doi:10.1016/j.foodchem.2006.01.046.

[26] P. Songchotikunpan, J. Tattiyakul, P. Supaphol, Extraction and electrospinning of gelatin from fish skin, Int J Biol Macromol. 42 (2008) 247-255. doi:10.1016/j.ijbiomac.2007.11.005.

[27] P. Gómez-Guillén, M. C., Turnay, J., Fernández-Díaz, M. D., Ulmo, N., Lizarbe, M. A., Montero, Structural and physical properties of gelatin extracted from different marine species: a comparative study., Food Hydrocoll. 16 (2002) 25-34.

[28] A. Sila, O. Martinez-Alvarez, F. Krichen, M.C. Gómez-Guillén, A. Bougatef, Gelatin prepared from European eel (Anguilla anguilla) skin: Physicochemical, textural, viscoelastic and surface properties, Colloids Surfaces A Physicochem Eng Asp. 529 (2017) 643-650. doi:10.1016/j.colsurfa.2017.06.032.

[29] W.C. G. Strasburg, Y.L. Xiong, Physiology and chemistry of edible muscle tissues, in: C. Press (Ed.), Fennema's Food Chem, London, 2007: pp. 923-973.

[30] M.A. Amiza, D. Siti Aishah, Effect of drying and freezing of Cobia (Rachycentron canadum) skin on its gelatin properties, Int Food Res J. 18 (2011) 159-166.

[31] P. Kittiphattanabawon, S. Benjakul, W. Visessanguan, H. Kishimura, F. Shahidi, Isolation and Characterisation of collagen from the skin of brownbanded bamboo shark (Chiloscyllium punctatum), Food Chem. 119 (2010) 1519-1526. doi:10.1016/j.foodchem.2009.09.037.

[32] P. Singh, S. Benjakul, S. Maqsood, H. Kishimura, Isolation and characterisation of collagen extracted from the skin of striped catfish (Pangasianodon hypophthalmus), Food Chem. 124 (2011) 97-105. doi:10.1016/j.foodchem.2010.05.111.

[33] S. Benjakul, K. Oungbho, W. Visessanguan, Y. Thiansilakul, S. Roytrakul, Characteristics of gelatin from the skins of bigeye snapper, Priacanthus tayenus and Priacanthus macracanthus, Food Chem. 116 (2009) 445-451. doi:10.1016/j.foodchem.2009.02.063.

[34] S. Savadkoohi, H. Hoogenkamp, K. Shamsi, A. Farahnaky, Color, sensory and textural attributes of beef frankfurter, beef ham and meat-free sausage containing

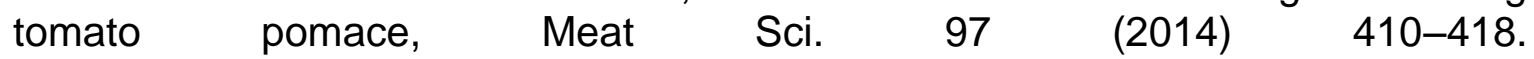
doi:10.1016/j.meatsci.2014.03.017.

[35] M.I. Castro-González, M. Méndez-Armenta, Heavy metals: Implications associated to fish consumption, Environ Toxicol Pharmacol. 26 (2008) 263-271. doi:10.1016/j.etap.2008.06.001.

[36] J. Tkaczewska, M. Morawska, P. Kulawik, M. Zając, Characterization of carp (Cyprinus carpio) skin gelatin extracted using different pretreatments method, 
Food Hydrocoll. 81 (2018) 169-179. doi:10.1016/j.foodhyd.2018.02.048.

[37] I. Kołodziejska, E. Skierka, M. Sadowska, W. Kołodziejski, C. Niecikowska, Effect of extracting time and temperature on yield of gelatin from different fish offal, Food Chem. 107 (2008) 700-706. doi:10.1016/j.foodchem.2007.08.071.

[38] N. Cebi, M.Z. Durak, O.S. Toker, O. Sagdic, M. Arici, An evaluation of Fourier transforms infrared spectroscopy method for the classification and discrimination of bovine, porcine and fish gelatins, Food Chem. 190 (2016) 1109-1115. doi:10.1016/j.foodchem.2015.06.065.

[39] S. Sinthusamran, S. Benjakul, H. Kishimura, Molecular characteristics and properties of gelatin from skin of seabass with different sizes, Int J Biol Macromol. 73 (2015) 146-153. doi:10.1016/j.jbiomac.2014.11.024.

[40] S. Sinthusamran, S. Benjakul, H. Kishimura, Characteristics and gel properties of gelatin from skin of seabass (Lates calcarifer) as influenced by extraction conditions, Food Chem. 152 (2014) 276-284. doi:10.1016/j.foodchem.2013.11.109.

[41] B.B. Doyle, E.G. Bendit, E.R. Blout, Infrared spectroscopy of collagen and collagen-like polypeptides, Biopolymers. 14 (1975) 937-957. doi:10.1002/bip.1975.360140505.

[42] J.H. Muyonga, C.G.B. Cole, K.G. Duodu, Characterisation of acid soluble collagen from skins of young and adult Nile perch (Lates niloticus), Food Chem. 85 (2004) 81-89. doi:10.1016/j.foodchem.2003.06.006.

[43] D.M. Hashim, Y.B.C. Man, R. Norakasha, M. Shuhaimi, Y. Salmah, Z.A. Syahariza, Potential use of Fourier transform infrared spectroscopy for differentiation of bovine and porcine gelatins, Food Chem. 118 (2010) 856-860. doi:10.1016/j.foodchem.2009.05.049.

[44] M. Nagarajan, S. Benjakul, T. Prodpran, P. Songtipya, Characteristics and functional properties of gelatin from splendid squid (Loligo formosana) skin as affected by extraction temperatures, Food Hydrocoll. 29 (2012) 389-397. doi:10.1016/j.foodhyd.2012.04.001.

[45] E. Badea, L. Miu, P. Budrugeac, M. Giurginca, A. Mašić, N. Badea, G. Della Gatta, Study of deterioration of historical parchments by various thermal analysis techniques complemented by SEM, FTIR, UV-Vis-NIR and unilateral NMR investigations, J Therm Anal Calorim. 91 (2008) 17-27. doi:10.1007/s10973-0078513-x.

[46] G. Al-Saidi, M.S. Rahman, A. Al-Alawi, N. Guizani, Thermal characteristics of gelatin extracted from shaari fish skin Effects of extraction conditions, J Therm Anal Calorim. 104 (2011) 593-603. doi:10.1007/s10973-010-1240-8.

[47] B. Giménez, J. Turnay, M.A. Lizarbe, P. Montero, M.C. Gómez-Guillén, Use of lactic acid for extraction of fish skin gelatin, Food Hydrocoll. 19 (2005) 941-950. doi:10.1016/j.foodhyd.2004.09.011. 
[48] M. Safandowska, K. Pietrucha, Effect of fish collagen modification on its thermal and rheological properties, Int J Biol Macromol. 53 (2013) 32-37. doi:10.1016/j.ijbiomac.2012.10.026.

[49] P. Kittiphattanabawon, S. Benjakul, W. Visessanguan, F. Shahidi, Isolation and characterization of collagen from the cartilages of brownbanded bamboo shark (Chiloscyllium punctatum) and blacktip shark (Carcharhinus limbatus), LWT Food Sci Technol. 43 (2010) 792-800. doi:10.1016/j.Iwt.2010.01.006.

[50] Q. Jin, Z. Cai, X. Li, M.P. Yadav, H. Zhang, Comparative viscoelasticity studies: Corn fiber gum versus commercial polysaccharide emulsifiers in bulk and at air/liquid interfaces, Food Hydrocoll. $64 \quad$ (2017) 85-98. doi:10.1016/j.foodhyd.2016.11.002.

[51] A. Romero, T. Verwijlen, A. Guerrero, J. Vermant, Interfacial behaviour of crayfish $\begin{array}{lllll}\text { protein isolate, Food Hydrocoll. } 30 & \text { (2013) 470-476. }\end{array}$ doi:10.1016/j.foodhyd.2012.07.009.

[52] Y. Liu, L. Xia, H. Jia, Q. Li, W. Jin, X. Dong, J. Pan, Physiochemical and functional properties of chum salmon (Oncorhynchus keta) skin gelatin extracted at different temperatures, J Sci Food Agric. 97 (2017) 5406-5413. doi:10.1002/jsfa.8431.

[53] M. Chen, G. Sala, M.B.J. Meinders, H.J.F. van Valenberg, E. van der Linden, L.M.C. Sagis, Interfacial properties, thin film stability and foam stability of casein micelle dispersions, Colloids Surfaces B Biointerfaces. 149 (2017) 56-63. doi:10.1016/j.colsurfb.2016.10.010. 
Fig. 1. SDS-PAGE of sample $A, B, C$ and $D$.

Fig. 2. FTIR spectra, absorbance $(A U)$ as a function of wavenumber $\left(\mathrm{cm}^{-1}\right)$, of sample $A, B, C$ and $D$, respectively.

Fig. 3. DSC thermograms of sample $A, B, C$ and $D$.

Fig. 4. $\zeta$-potential $(\mathrm{mV})$ as a function of $\mathrm{pH}$ for the sample $\mathrm{A}, \mathrm{B}, \mathrm{C}$ and $\mathrm{D}$.

Fig. 5. G' and G' frequency sweep at the air-water interface (A). G' and G" as a function of time at the air-water interface (B). All experiments were performed at thermostated constant temperature $\left(20 \pm 0.01^{\circ} \mathrm{C}\right)$.

Fig. 6. (A) Foam capacity for the sample A, B, C and D. (B) Foam stability as a function of the time $(\mathrm{min})$ for the sample $A(\bullet), B(\square), C(\bullet)$ and $D(\Delta)$. Determinations were performed in duplicate for 2 different preparations of suspensions. All experiments were performed at thermostated constant temperature $\left(21^{\circ} \mathrm{C}\right)$. 
Table 1 Physico-chemical composition of the sample A, B, C and D.

Sample

A

B

C

Moisture (\%)

$5.41 \pm 0.64$

$11.73 \pm 0.08$

$7.09 \pm 0.06$

$4.81 \pm 1.28$
Ash (\%)

$0.14 \pm 0.12$

$0.18 \pm 0.03$

$27.62 \pm 0.11$

$24.39 \pm 1.06$
Protein (\%)

$95.36 \pm 0.23$

$94.24 \pm 0.72$

$71.33 \pm 0.34$

$60.34 \pm 1.48$
Fat (\%)

$0.32 \pm 0.18$

$0.29 \pm 0.00$

$0.78 \pm 1.09$

$0.05 \pm 0.01$ 
Table 2 Color determination of the sample A, B, C and D.

\begin{tabular}{cccc}
\hline Sample & $\mathrm{L}^{*}$ & $\mathrm{a}^{*}$ & $\mathrm{~b}^{*}$ \\
\hline A & & & \\
B & $94.2 \pm 0.0$ & $-2.27 \pm 0.1$ & $13.2 \pm 0.5$ \\
C & $99.8 \pm 0.3$ & $-0.80 \pm 0.1$ & $27.2 \pm 0.3$ \\
D & $96.7 \pm 0.0$ & $-1.10 \pm 0.0$ & $4.58 \pm 0.1$ \\
& $97.1 \pm 0.1$ & $-1.19 \pm 0.0$ & $4.25 \pm 0.1$ \\
\hline
\end{tabular}


Table 3 Amino acid composition for the sample A, B, C and D expressed as residues/1000 residues.

\begin{tabular}{lcccc}
\hline $\begin{array}{c}\text { Amino acid } \\
\text { (residues/1000 residues) }\end{array}$ & A & B & C & D \\
\hline Arginine & 64 & 58 & 57 & 74 \\
Serine & 43 & 68 & 65 & 68 \\
Hydroxyproline & 99 & 68 & 73 & 71 \\
Glycine & 252 & 271 & 289 & 272 \\
Threonine & 26 & 25 & 15 & 28 \\
Alanine & 93 & 93 & 102 & 85 \\
Proline & 107 & 94 & 105 & 92 \\
Methionine & 12 & 17 & 7 & 12 \\
Aspartic acid & 58 & 63 & 60 & 58 \\
Valine & 50 & 49 & 52 & 45 \\
Histidine & 7 & 10 & 5 & 9 \\
Lysine & 35 & 28 & 28 & 33 \\
Glutamic acid & 91 & 95 & 113 & 99 \\
Tryptophan & 0 & 0 & 0 & 0 \\
Leucine & 26 & 23 & 10 & 20 \\
Phenylalanine & 15 & 15 & 7 & 13 \\
Isoleucine & 20 & 22 & 11 & 20 \\
C-C & 0 & 0 & 0 & 0 \\
Tyrosine & 3 & 3 & 2 & 3 \\
& & & & \\
\hline
\end{tabular}




\section{Author statement}

Federico Casanova and Mastaneh Jahromi: Conceptualization, Methodology, Validation, Formal analysis, Investigation, Data Curation, Writing - Original Draft, Writing Review \& Editing. Heidi Olander Petersen: Formal analysis. Karin Loft Eybye, Sara Kobbelgaard and Greta Jakobsen: Conceptualization, Methodology, Validation. Mohammad Amin Mohammadifar and Flemming Jessen: Supervision and Project administration. 


\section{Abstract}

Gelatin from saithe (Pollachius virens) skin, with high mineral content, was characterized and compared to marine gelatin from the market. As expected, gelatin extracted from the saithe skin had a high mineral content (>20\%), compared to commercial gelatin $(<0.2 \%)$. SDS-PAGE analysis revealed the presence of $\alpha$-chains, $\beta$-chains and other high molecular weight aggregates. The absorption bands of gelatin in FTIR spectra were mainly situated in the amide band region (amide A, Amide B, amide I, amide II and amide III), whereas DSC thermograms showed typical gelatin behavior. Interesting viscoelastic and higher foaming properties were observed for the saithe gelatins, compared to the market gelatins, probably due to the presence of high sea mineral content. The potential applications in food and cosmetic area of gelatin with high mineral content are presented and discussed in the conclusions. 


\section{Highlights}

- High mineral content gelatin from saithe (Pollachius virens) skin compared to commercial gelatin.

- No difference was observed in terms of physico-chemical and structural characteristics between gelatin from saithe (Pollachius virens) and commercial gelatin.

- The presence of high mineral content allowed better foam stability. 
$\begin{array}{llll}\text { Marker A } & \text { B } & \text { C } & \text { D }\end{array}$

$200 \mathrm{KDa} \longrightarrow$

$116 \mathrm{KDa} \longrightarrow$

$66 \mathrm{KDa} \longrightarrow$

$55 \mathrm{KDa} \longrightarrow$

$36 \mathrm{KDa} \longrightarrow$

$31 \mathrm{KDa} \longrightarrow$

$21 \mathrm{KDa} \longrightarrow$

Figure 1 

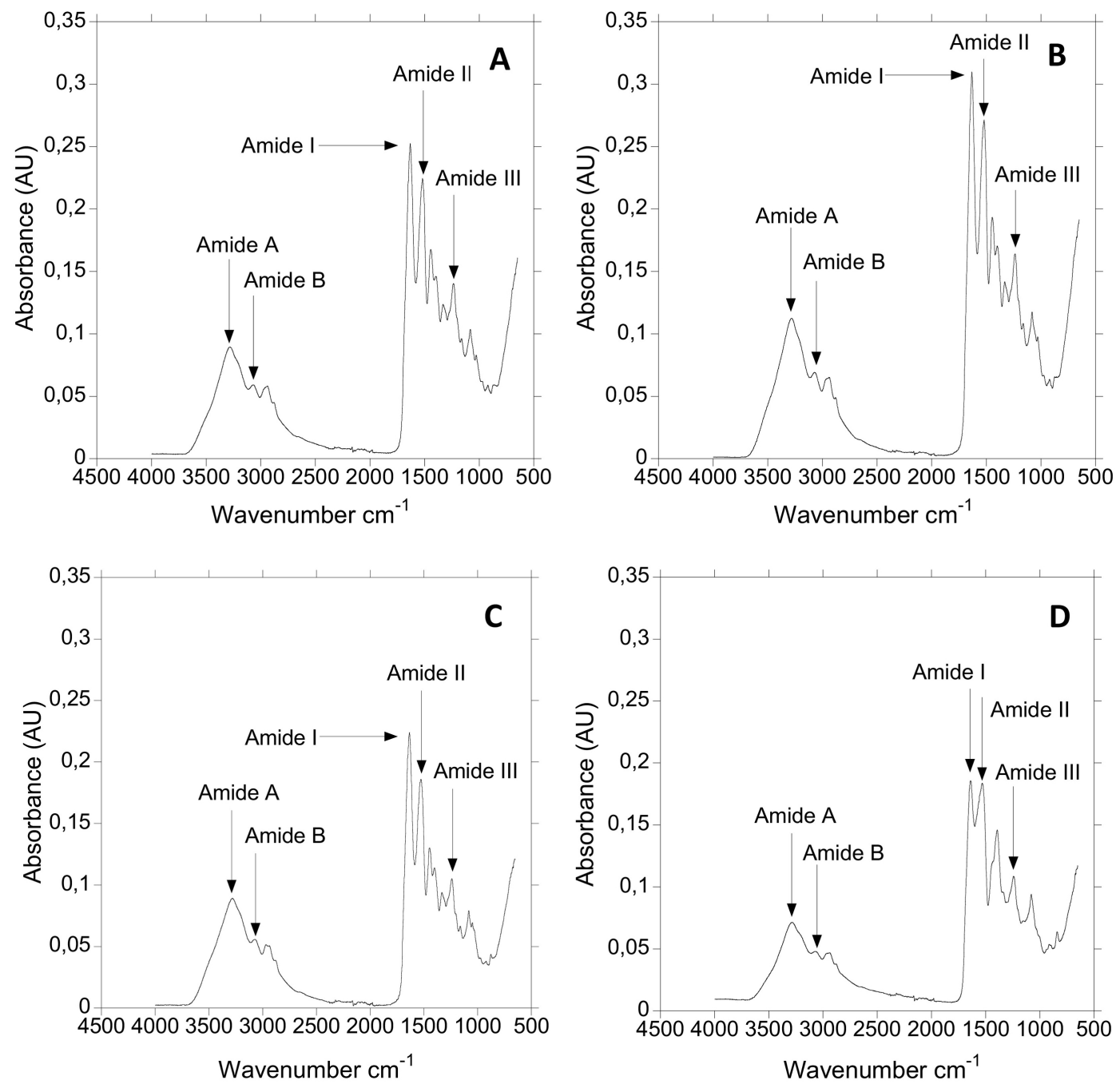

Figure 2 

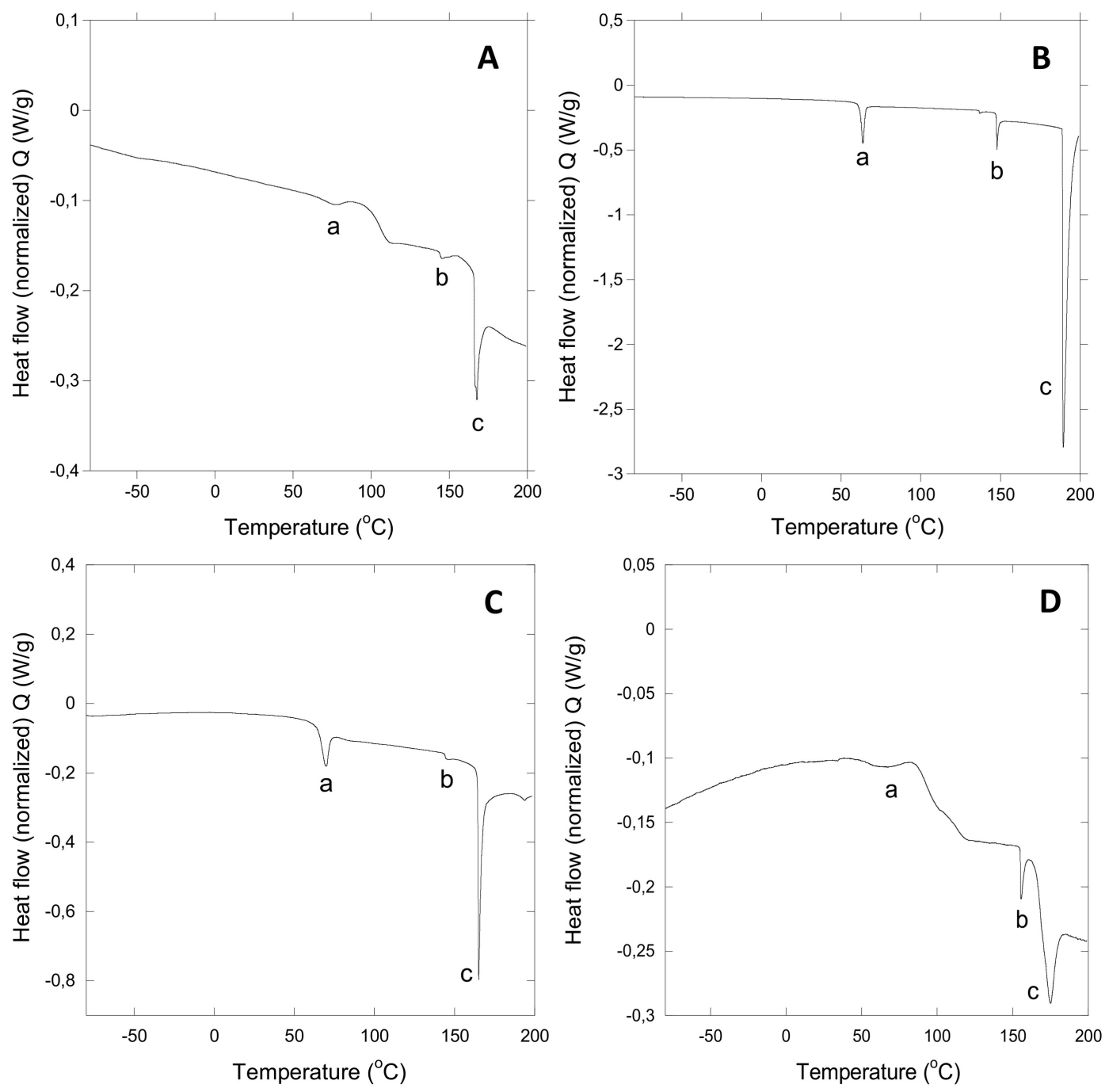

Figure 3 

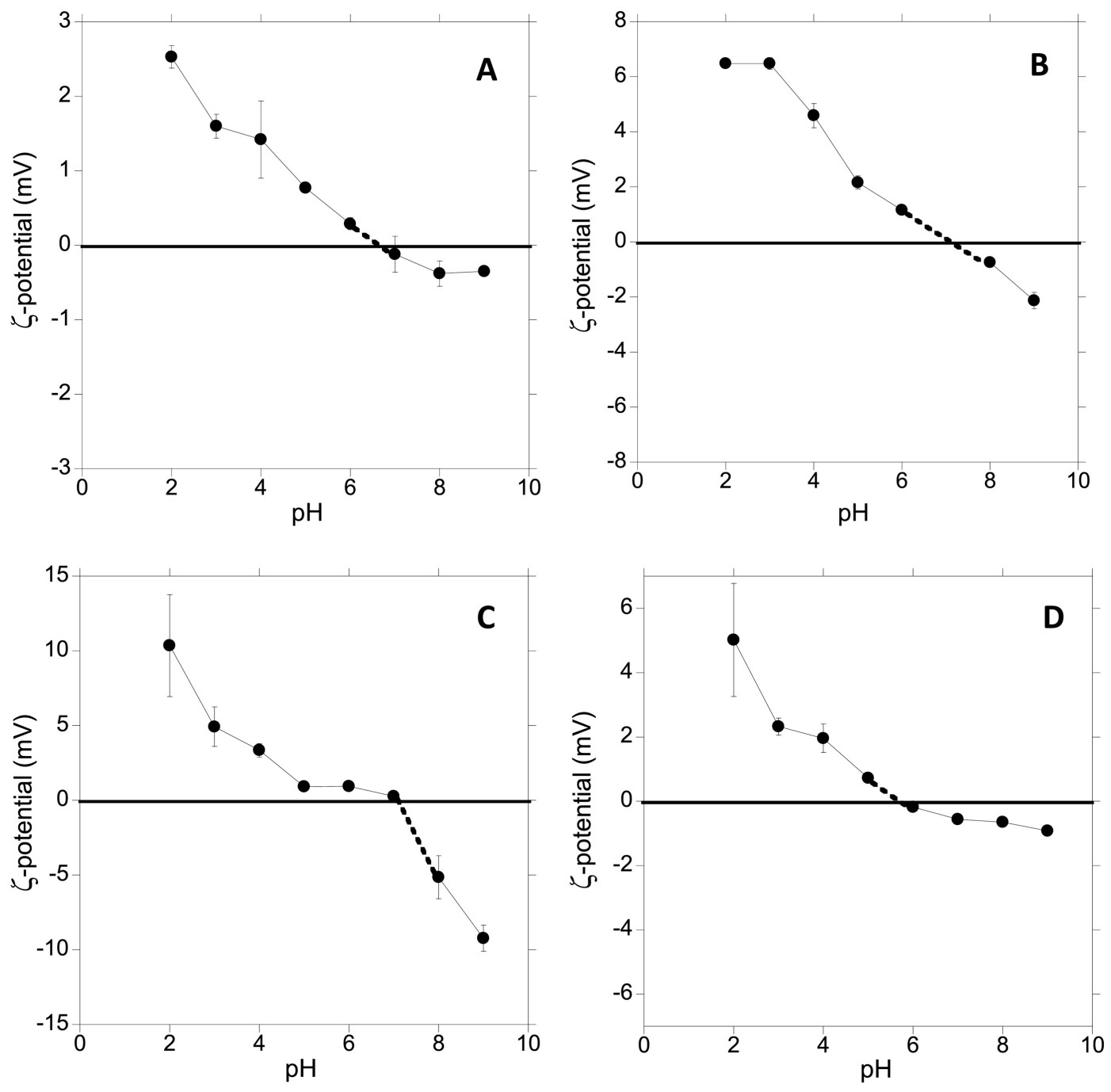

Figure 4 

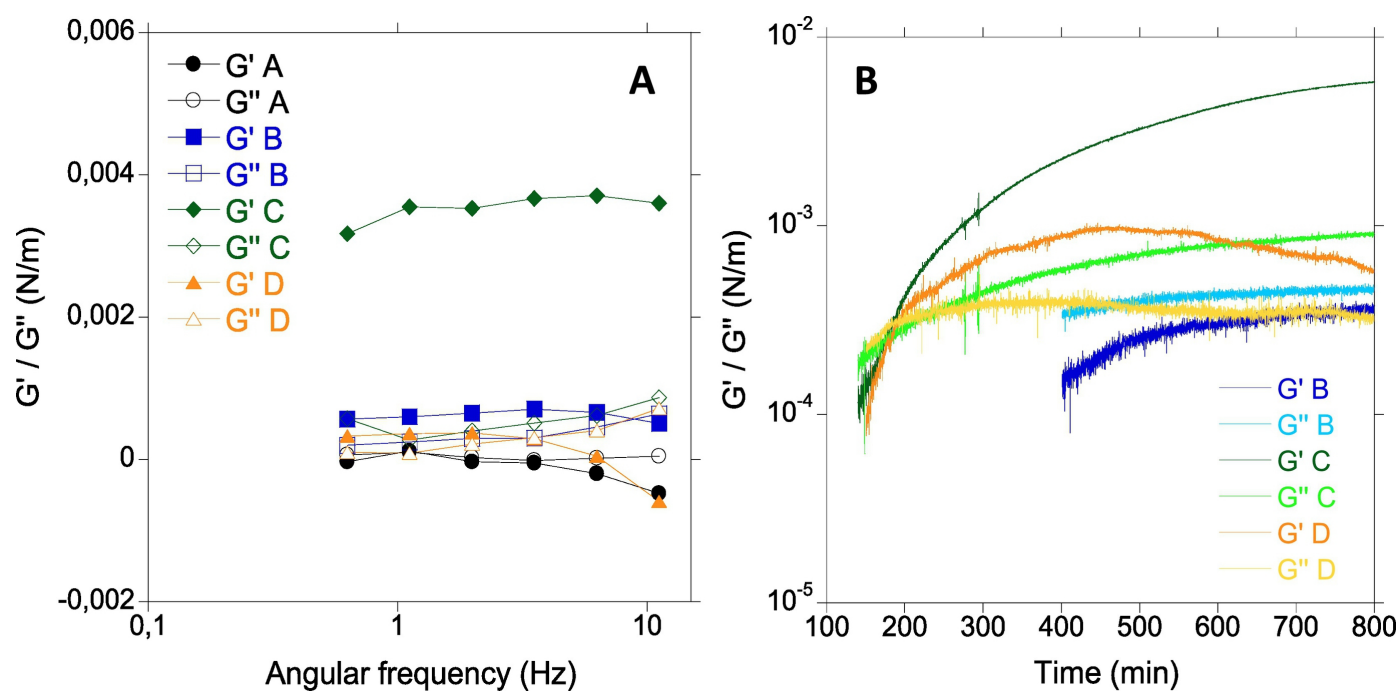

Figure 5 


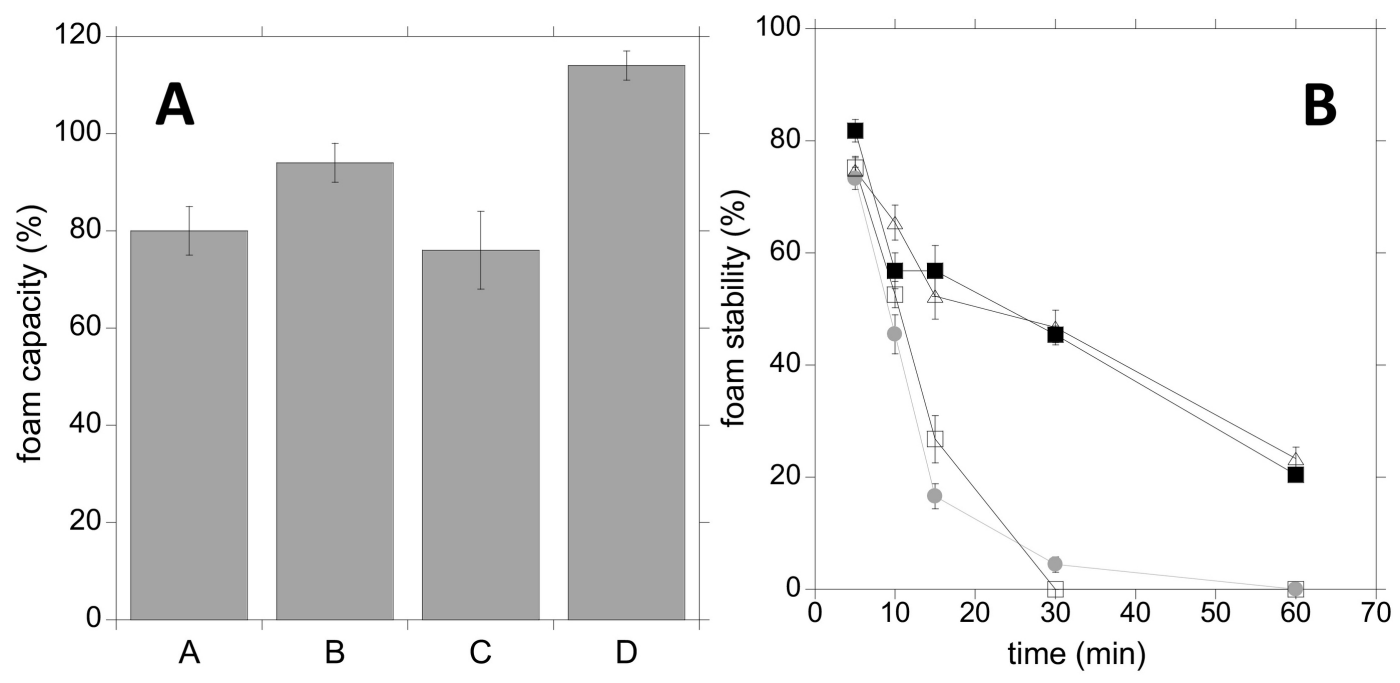

Figure 6 